\title{
Pengaruh Penerapan Model PBL Terhadap Kemampuan Pemecahan Masalah Matematika Siswa SMP PGRI (Disamakan) Sungguminasa
}

\author{
Sitti Rahmah Tahir ${ }^{*}$ \\ ${ }_{1}$ Pendidikan Matematika, FKIP, Universitas Muhammadiyah Makassar, Makkasar \\ *email: rahmahtahir85@gmail.com
}

\begin{abstract}
One ability that students must master is problem solving. Increasing students' problem-solving ability will improve their mindset. The alternative used to increase students' problem-solving ability is applying Problem Based Learning model. This study aims to understand the presence or absence of the application of the model of the application of Problem Based Learning to the problem solving of students of class VII PGRI (Equated) Sungguminasa. This type of research is a quasiexperimental design of the Control Posttest Group. The population in this study in all VII class SMP PGRI (Disamakan) Sungguminasa and selected class VII A as an experimental class with consultations with the Problem Based Learning model and class VII C as a control class with training in direct learning models involving the community. The technique of collecting data in this study is the test then analyzed with descriptive and inferential statistics using the test (Independent Sample t-test). Based on the results of the study concluded that the Problem Based Learning model determines the problem-solving abilities of students of class VII SMP PGRI (Disamakan) Sungguminasa.
\end{abstract}

Keywords: Problem Solving Ability; Problem Based Learning Model; Direct Learning Model

\begin{abstract}
Abstrak
Salah satu kemampuan yang harus dikuasai oleh siswa adalah pemecahan masalah. Meningkatkan kemampuan siswa dalam memecahkan masalah akan berpengaruh pada peningkatan mindset siswa. Salah satu cara yang digunakan untuk meningkatkan kemapuan pemecahan masalah siswa adalah dengan mengaplikasikan model Problem Based Learning. Penelitian ini bertujuan untuk mengetahui ada tidaknya pengaruh penerapan model Problem Based Learning terhadap kemampuan pemecahan masalah matematika siswa kelas VII SMP PGRI (Disamakan) Sungguminasa. Jenis penelitian ini adalah quasi eksperimen dengan desain Control Group Posttest Design. Populasi dalam penelitian ini seluruh kelas VII SMP PGRI (Disamakan) Sungguminasa dan terpilih kelas VII A sebagai kelas eksperimen dengan perlakuan model Problem Based Learning dan kelas VII C sebagai kelas kontrol dengan perlakuan model pembelajaran langsung yang mewakili populasi. Teknik pengumpulan data dalam penelitian ini yaitu tes kemudian dianalisis dengan statistik deskriptif dan inferensial menggunakan uji t (Independent Sample t-test). Berdasarkan hasil penelitian disimpulkan bahwa model Problem Based Learning berpengaruh terhadap kemampuan pemecahan masalah matematika siswa kelas VII SMP PGRI (Disamakan) Sungguminasa.
\end{abstract}

Kata Kunci: Kemampuan Pemecahan Masalah; Model Problem Based Learning; Model Direct Learning

\section{Cara Mengutip}




\section{PENDAHULUAN}

Pendidikan merupakan proses untuk membantu manusia dalam mengembangkan potensi dalam dirinya serta untuk meningkatkan harkat dan martabat manusia, sehingga manusia mampu untuk menghadapi setiap perubahan yang terjadi menuju arah yang baik. Berdasarkan UU nomor 20 pasal 1 tahun 2003 tentang Sistem Pendidikan Nasional, dapat disimpulkan bahwa pendidikan menjadi salah satu upaya untuk meningkatkan dan mengembangkan sumber daya manusia di segala bidang untuk memiliki kesiapan dalam menghadapi kemajuan ilmu pengetahuan dan teknologi.

Untuk mengatasi masalah tersebut, diperlukan usaha dari guru selaku pendidik untuk menciptakan suasana belajar yang mampu meningkatkan kemampuan pemecahan masalah matematika siswa (Maulyda et al., 2019). Salah satu model pembelajaran yang dapat meningkatkan kemampuan pemecahan masalah matematika siswa adalah model Problem Based Learning (PBL). Menurut Syahputra \& Surya (2017) bahwa model ini tepat untuk meningkatkan kemampuan pemecahan masalah matematis siswa. Dalam proses pembelajaran aktivitas siswa itu dimulai dengan observasi, kemudian mengajukan pertanyaan, mecoba, membuat jaringan dan menganalisis.

Duch dalam Aris Shoimin (2014: 130) mengemukakan bahwa PBL (Problem based learning) atau Pembelajaran Berbasis Masalah adalah model pembelajaran yang bercirikan adanya permasalahan nyata sebagai konteks untuk para peserta didik belajar berfikir kritis dan keterampilan memecahkan masalah serta memperoleh pengetahuan.

Problem Based Learning diyakini dapat menumbuhkembangkan kemampuan kreativitas siswa, baik secara individual maupun secara kelompok karena di setiap langkah menuntut adanya keaktifan siswa seingga keberhasilan model Problem Based Learning sangat tergantung pada ketersediaan sumber belajar bagi siswa, alat-alat untuk menguji jawaban dan dugaan. Menuntut adanya perlengkapan praktikum, memerlukan waktu yang cukup apalagi data harus diperoleh dari lapangan, serta kemampuan guru dalam mengangkat dan merumuskan masalah.

Menurut J. Suprihatiningrum ada beberapa prosedur penerapan dalam pembelajaran model problem based learning, yaitu dijelaskan dalam tabel sebagai berikut:

Tabel 1. Sintaks Problem Based Learning

\begin{tabular}{lll}
\hline \multicolumn{1}{c}{ Tahap } & \multicolumn{3}{c}{ Tingkah Laku Guru } \\
\hline Tahap 1 & Guru menjelaskan tujuan pembelajaran, \\
Orientasi siswa pada masalah & menjelaskan logistik yang dibutuhkan, mengajukan \\
& fenomena, demontrasi, atau cerita untuk \\
\hline
\end{tabular}




\begin{tabular}{ll}
\hline Mandalika Mathematics and Education Journal \\
Volume 2 Nomor 1, Juni 2020 \\
e-ISSN 2715-1190। I p-ISSN 2715-8292
\end{tabular}

Model pembelajaran PBL (Problem Based Learning) menurut Aris Shoimin (2014: 132) memiliki beberapa kelebihan yaitu, siswa didorong untuk memiliki kemampuan memecahkan masalah dalam situasi nyata, siswa memiliki kemampuan membangun pengetahuannya sendiri melalui aktivitas belajar, pembelajaran berfokus pada masalah, sehingga materi yang tidak ada hubungannya tidak perlu dipelajari oleh siswa, terjadi aktivitas ilmiah pada siswa melalui kerja kelompok, siswa terbiasa menggunakan sumber-sumber pengetahuan, siswa memiliki kemampuan menilai kemajuan belajarnya sendiri, siswa memiliki kemampuan untuk melakukan komunikasi ilmiah dalam kegiatan diskusi atau presentasi hasil pekerjaan mereka, dan kesulitan belajar siswa secara individual dapat diatasi melalui kerja kelompok.

Model pembelajaran PBL (Problem Based Learning) akan cocok jika diterapkan pada materi pembelajaran yang menuntuk kemampuan tertentu yang kaitannya dengan pemecahan masalah, maka dari itu mempunyai beberapa kekurangan. Aris Shoimin (2014: 132) mengemukakan bahwa model pembelajaran PBL (Problem Based Learning) mempunyai kekurangan-kekurangan yaitu, PBL (Problem Based Learning) tidak dapat diterapkan untuk setiap materi pelajaran dan dalam suatu kelas memiliki tingkat keragaman siswa yang tinggi akan terjadi kesulitan dalam pembagian tugas.

Dalam matematika, kemampuan pemecahan masalah harus dimiliki oleh siswa untuk menyelesaikan soal-soal berbasis masalah. Keterampilan memecahkan masalah tersebut dapat dimiliki oleh siswa bila guru mengajarkan bagaimana cara memecahkan masalah yang efektif. Akan tetapi, lemahnya penguasan konsep dan prinsip oleh siswa dapat mengakibatkan kemampuan siswa dalam pemecahan masalah akan menjadi lemah pula. 


\section{Mandalika Mathematics and Education Journal \\ Volume 2 Nomor 1, Juni 2020 e-ISSN 2715-1190 | | p-ISSN 2715-8292 \\ DOI: http://dx.doi.org/10.29303/mandalika.v2i1.1775}

Menurut Polya (Cahyani Hesti, 2016:153), ada empat tahap pemecahan masalah yaitu memahami masalah, merencanakan penyelesaian masalah, melakukan perencanaan masalah, dan melihat kembali hasil yang diperoleh.

Model pembelajaran langsung menurut Arends (Supriyono, 2014:3) adalah "salah satu pendekatan mengajar yang dirancang khusus untuk menunjang proses belajar siswa yang berkaitan dengan pengetahuan deklaratif dan pengetahuan prosedural yang terstruktur dengan baik yang dapat diajarkan dengan pola kegiatan yang bertahap, selangkah demi selangkah".

Kelebihan dan Kelemahan Model Pembelajaran Langsung menurut Widaningsih (Supriyono, 2014:4) adalah sebagai berikut : Kelebihan model pembelajaran langsung (1) Relatif banyak materi yang bisa tersampaikan. (2) Untuk hal-hal yang sifatnya prosedural, model ini akan relatif mudah diikuti. Sedangkan kekurangan/kelemahan model pembelajaran langsung adalah jika terlalu dominan pada ceramah, maka siswa merasa cepat bosan.

Pada pengajaran langsung terdapat lima fase yang sangat penting. Sintaks model pembelajaran langsung (Trianto dalam Risdiyanto 2012:2) ada 5 fase yaitu

1. Fase 1 menyampaikan tujuan dan mempersiapkan siswa

2. Fase 2 mendemonstrasikan pengetahuan dan keterampilan

3. Fase 3 membimbing pelatihan

4. Fase 4 mengecek pemahaman dan memberikan umpan balik

5. Fase 5 memberikan kesempatan untuk pelatihan lanjutan dan penerapan.

\section{METODE}

Pendekatan penelitian yang digunakan oleh peneliti adalah penelitian kuantitatif. Penelitian yang digunakan dalam penelitian ini adalah penelitian eksperimen. Dalam penelitian eksperimen terdapat suatu perlakuan (treatment). Jenis penelitian eksperimen yang digunakan dalam penelitian ini adalah quasi experimen. Penelitian ini mengambil dua kelas sebagai sampel. Desain yang digunakan dalam penelitian ini adalah Control Group Posttest Design (Sugiyono, 2012).

Populasi dalam penelitian ini adalah seluruh siswa kelas VII SMP PGRI (Disamakan) Sungguminasa. Sampel penelitian yang diambil dalam penelitian ini adalah dua kelas yang terdiri dari kelas eksperimen dan kelas kontrol. Sampel yang digunakan dalam penelitian ini dipilih menggunakan Cluster Random Sampling, Pengambilan dilakukan secara acak karena keadaan dari masing-masing kelas VII SMP PGRI (Disamakan) Sungguminasa relatif sama.

Untuk menganalisis data yang sudah terkumpul, teknik analisis data yang digunakan adalah analisis Statistik Deskriptif dan analisis Statistik Inferensial. Hasil analisis 


\section{Mandalika Mathematics and Education Journal \\ Volume 2 Nomor 1, Juni 2020 e-ISSN 2715-1190 | | p-ISSN 2715-8292 \\ DOI: http://dx.doi.org/10.29303/mandalika.v2i1.1775}

statistik deskriptif dalam penelitian ini meliputi nilai rata-rata, median, modus, standar deviasi, varians, rentang nilai, nilai maksimum dan nilai minimum. Sedangkan teknik analisis statistik inferensial dalam penelitian ini meliputi uji normalitas menggunakan uji Kolmogrov-Smirnov, uji homogenitas menggunakan uji Lavene's Tes for Equality of Variances, dan uji hipotesis menggunakan uji Independent Sample t test.

\section{HASIL DAN PEMBAHASAN}

\subsection{Analisis Statistik Deskriptif}

Berikut ini akan diuraikan hasil analisis deskriptif yaitu kemampuan pemecahan masalah sesudah penerapan model problem based learning. Uraian dari masing-masing deskripsi hasil analisis sebagai berikut:

\subsubsection{Deskripsi dan Distribusi Frekuensi Kemampuan Pemecahan Masalah Matematika Siswa Setelah diberikan Perlakuan (Posttest) Pada Kelas Eksperimen dan Kelas Kontrol}

Data kemampuan pemecahan masalah siswa yang didapat melalui tes kemampuan pemecahan masalah sesudah pembelajaran sebagai berikut:

Tabel 2. Deskripsi Kemampuan Pemecahan Masalah Matematika Siswa pada Kelas Eksperimen Setelah Perlakuan (Posttest)

\begin{tabular}{cc}
\hline Statistik & Nilai \\
\hline Sampel & 31 \\
\hline Mean & 77,55 \\
\hline Median & 80,00 \\
\hline Mode & 80 \\
\hline Standard Deviasi & 10,667 \\
\hline Varians & 113,789 \\
\hline Range & 44 \\
\hline Nilai Minimum & 50 \\
\hline Nilai Maksimum & 94
\end{tabular}

Tabel 3. Distribusi Frekuensi Kemampuan Pemecahan Masalah Matematika Siswa pada Kelas Eksperimen Setelah Perlakuan (Posttest)

\begin{tabular}{ccc}
\hline Interval & Kategori & Frekuensi \\
\hline $85,00-100,00$ & Sangat Tinggi & 8 \\
\hline $70,00-84,99$ & Tinggi & 16 \\
\hline $55,00-69,99$ & Sedang & 5 \\
\hline $40,00-54,99$ & Rendah & 2 \\
\hline $0,00-39,99$ & Sangat Rendah & 0 \\
\hline
\end{tabular}


Tabel 4. Statistik Deskripsi Kemampuan Pemecahan Masalah Matematika Siswa pada Kelas Kontrol Setelah Perlakuan (Posttest)

\begin{tabular}{cc}
\hline Statistik & Nilai \\
\hline Sampel & 31 \\
\hline Mean & 61,35 \\
\hline Median & 62,00 \\
\hline Mode & 68 \\
\hline Standard Deviasi & 13,180 \\
\hline Varians & 173,703 \\
\hline Range & 52 \\
\hline Nilai Minimum & 34 \\
\hline Nilai Maksimum & 86
\end{tabular}

Tabel 5. Distribusi Frekuensi Kemampuan Pemecahan Masalah Matematika Siswa pada Kelas kontrol Setelah Perlakuan (Posttest)

\begin{tabular}{ccc}
\hline Interval & Kategori & Frekuensi \\
\hline $85,00-100,00$ & Sangat Tinggi & 2 \\
\hline $70,00-84,99$ & Tinggi & 7 \\
\hline $55,00-69,99$ & Sedang & 12 \\
\hline $40,00-54,99$ & Rendah & 8 \\
\hline $0,00-39,99$ & Sangat Rendah & 2 \\
\hline
\end{tabular}

\subsubsection{Deskripsi Perbandingan Kemampuan Pemecahan Masalah Matematika Siswa Pada Kelas Eksperimen dan Kelas Kontrol}

Data mengenai kemampuan pemecahan masalah siswa yang didapat melalui tes kemampuan pemecahan masalah sesudah pembelajaran dapat dilihat pada tabel sebagai berikut:

Tabel 6. Statistik Perbandingan Kemampuan Pemecahan Masalah Matematis Siswa pada kelas Eksperimen dan Kelas Kontrol

\begin{tabular}{lccccccc} 
& N & Range & Xmin & Xmax & Mean & Std. Deviation & Variance \\
\hline $\begin{array}{l}\text { Post-Test } \\
\text { Eksperimen }\end{array}$ & 31 & 44 & 50 & 94 & 77.55 & 10.667 & 113.789 \\
\hline Post-Test Kontrol & 31 & 52 & 34 & 86 & 61.35 & 13.180 & 173.703 \\
& & & & & & & \\
\hline Valid N (listwise) & 31 & & & & & & \\
\hline
\end{tabular}




\section{Mandalika Mathematics and Education Journal \\ Volume 2 Nomor 1, Juni 2020 e-ISSN 2715-1190 | | p-ISSN 2715-8292 \\ DOI: http://dx.doi.org/10.29303/mandalika.v2i1.1775}

\subsubsection{Deskripsi Kemampuan Pemecahan Masalah Matematika Siswa Setelah diberikan Perlakuan (Posttest) Pada Kelas Eksperimen dan Kelas Kontrol Tiap Indikator}

Peneliti menganalisis kemampuan pemecahan masalah matematika siswa pada kelas eksperimen dan kelas kontrol ditinjau dari setiap indikatornya yaitu, memahami masalah, merencanakan penyelesaian masalah, menyelesaikan masalah sesuai rencana dan menafsirkan hasil dapat dilihat pada table berikut:

Tabel 7. Ketercapaian Indikator Kemampuan Pemecahan Masalah Matematika

\begin{tabular}{|c|c|c|c|c|c|c|c|c|}
\hline \multirow{2}{*}{ No } & \multirow{2}{*}{ Indikator } & \multirow{2}{*}{$\begin{array}{l}\text { Skor } \\
\text { Ideal }\end{array}$} & \multicolumn{3}{|c|}{$\begin{array}{c}\begin{array}{c}\text { Problem Based } \\
\text { Learning }\end{array} \\
\end{array}$} & \multicolumn{3}{|c|}{ Pembelajaran Langsung } \\
\hline & & & $\begin{array}{l}\text { Skor } \\
\text { Siswa }\end{array}$ & $(\bar{x})$ & $(\%)$ & $\begin{array}{l}\text { Skor } \\
\text { Siswa }\end{array}$ & $(\bar{x})$ & $(\%)$ \\
\hline 1. & $\begin{array}{l}\text { Memahami } \\
\text { Masalah }\end{array}$ & 2 & 260 & 1,68 & $84 \%$ & 258 & 1,66 & $83 \%$ \\
\hline 2. & $\begin{array}{l}\text { Merencanakan } \\
\text { Penyelesaian } \\
\text { Masalah }\end{array}$ & 2 & 203 & 1,30 & $65,5 \%$ & 166 & 1,07 & $53,5 \%$ \\
\hline 3. & $\begin{array}{l}\text { Menyelesaikan } \\
\text { Masalah Sesuai } \\
\text { Rencana }\end{array}$ & 4 & 514 & 3,32 & $83 \%$ & 376 & 2,43 & $60,75 \%$ \\
\hline 4. & $\begin{array}{l}\text { Menafsirkan } \\
\text { Hasil }\end{array}$ & 2 & 228 & 1,47 & $73,5 \%$ & 137 & 0,88 & $44 \%$ \\
\hline
\end{tabular}

\subsection{Hasil Analisis Inferensial}

\subsubsection{Uji Normalitas}

Hasil perhitungan yang diperoleh untuk posttest pada kelas eksperimen dengan model Problem Based Leraning Pvalue $>\alpha$ (taraf signifikansi $\alpha=0,05$ ) yaitu 0,200 $>0,05$ dan hasil perhitungan yang diperoleh untuk nilai posttest pada kelas kontrol dengan model pembelajaran langsung yaitu $0,148>0,05$. Kriteria pengujiannya adalah data berdistribusi normal jika Pvalue $>\alpha$ sehingga dapat disimpulkan bahwa nilai posttest kedua kelas baik eksperimen maupun kelas kontrol termasuk dalam kategori Normal.

\subsection{Uji Homogenitas}

Hasil analisis data dengan menggunakan Lavene's Test, diperoleh hasil perhitungan untuk skor kemampuan pemecahan masalah matematika siswa Pvalue $>\alpha$ (taraf signifikan $\alpha=0,05$ ) yaitu $0,244>0,05$. Jadi dapat disimpulkan bahwa tidak ada perbedaan varians diantara kedua kelompok.

\subsection{Uji Hipotesis}

Diperoleh hasil analisis dengan menggunakan taraf signifikansi $5 \%$ tampak bahwa nilai $\mathrm{p}$ (sig.(2-tailed) ) adalah $0,000<0,05$. Ini berarti $\mathrm{H}_{0}$ ditolak dan $\mathrm{H}_{1}$ diterima yakni bahwa kemampuan pemecahn masalah matematika siswa pada kelas eksperimen yang diajar 


\section{Mandalika Mathematics and Education Journal \\ Volume 2 Nomor 1, Juni 2020 \\ e-ISSN 2715-1190 | | p-ISSN 2715-8292 \\ DOI: http://dx.doi.org/10.29303/mandalika.v2i1.1775}

melalui model Problem Based Learning lebih tinggi dari kemampuan pemecahan masalah matematika siswa pada kelas kontrol yang diajar melalui model pembelajaran langsung.

\subsection{Pembahasan}

Penelitian ini dilakukan di SMP PGRI (Disamakan) Sungguminasa, dengan populasi penelitian adalah seluruh siswa kelas VII pada semester genap tahun ajaran 2018/2019. Penelitian ini melibatkan dua kelas yaitu kelas eksperimen dan kelas kontrol dimana kelas VII A yang berjumlah 31 siswa sebagai kelas eksperimen dan kelas VII C yang berjumlah 31 siswa sebagai kelas kontrol.

Berdasarkan hasil penelitian yang telah diuraikan sebelumnnya maka secara deskriptif, kemampuan pemecahan masalah matematika siswa setelah mengikuti pembelajaran (posttest) dikelas eksperimen yang diajar dengan model problem Based Learning pada kelas VII A SMP PGRI (Disamakan) Sungguminasa pada materi himpunan diperoleh nilai rata-rata sebesar 77,55 dengan standard deviasi 10,667. Adapun median dari data tersebut diperoleh yaitu 80,00 dengan modus 80. Nilai minimum yang diperoleh siswa adalah 50 sedangkan nilai maksimum yang diperoleh siswa adalah 94 dengan rentang nilai (range) yaitu 44. Adapun distribusi frekuensinya yaitu diperoleh nilai terbanyak berada pada interval 70,00-84,99 dengan kategori tinggi sebanyak 16 siswa. Siswa yang memperoleh nilai terendah berada pada interval 40,00-54,99 dengan kategori rendah sebanyak 2 siswa, sedangkan siswa yang memperoleh nilai tertinggi berada pada interval 85,00-100,00 dengan kategori sangat tinggi sebanyak 8 siswa.

Adapun kemampuan pemecahan masalah matematika siswa setelah mengikuti pembelajaran (posttest) dikelas kontrol yang diajar dengan model pembelajaran langsung pada kelas VII C SMP PGRI (Disamakan) Sungguminasa pada materi himpunan diperoleh nilai rata-rata sebesar 61,35 dengan standard deviasi 13,180. Adapun median dari data tersebut diperoleh yaitu 62,00 dengan modus 68 . Nilai minimum yang diperoleh siswa adalah 34 sedangkan nilai maksimum yang diperoleh siswa adalah 86 dengan rentag nilai (range) yaitu 52. Adapun distribusi frekuensinya yaitu diperoleh nilai terbanyak berada pada interval 55,00-69,99 dengan kategori sedang sebanyak 12 siswa. Siswa yang memperoleh nilai terendah berada pada interval 0,00-39,99 dengan kategori sangat rendah sebanyak 2 siswa, sedangkan siswa yang memperoleh nilai tertinggi berada pada interval 85,00-100,00 dengan kategori sangat tinggi sebanyak 2 siswa.

Adapun perhitungan hasil posttest pada kelas Problem Based Learning dan Pembelajaran Langsung memperlihatkan adanya perbedaan statistik perolehan nilai oleh kedua kelas. Hasil perhitungan statistik menunjukan nilai tertinggi pada siswa kelas Problem Based Learning lebih besar dibandingkan dengan skor tertinggi di kelas Pembelajaran Langsung dengan selisih 8 poin yaitu nilai tertinggi kelas Problem Based 


\section{Mandalika Mathematics and Education Journal \\ Volume 2 Nomor 1, Juni 2020 e-ISSN 2715-1190 | | p-ISSN 2715-8292 \\ DOI: http://dx.doi.org/10.29303/mandalika.v2i1.1775}

Learning sebesar 94 dan nilai tertinggi kelas Pembelajaran Langsung 86. Dilihat dari skor terendahnya juga kelas Problem Based Learning lebih besar dibandingkan dengan kelas Pembelajaran Langsung dengan selisih 16 poin yaitu nilai terendah kelas Problem Based Learning adalah 50 sedangkan nilai terendah siswa kelas Pembelajaran Langsung 34.

Pada ukuran pemusatan data hasil posttest terlihat bahwa nilai rata-rata siswa kelas Problem Based Learning lebih tinggi daripada nilai rata-rata siswa kelas Pembelajaran Langsung dengan rata-rata 77,55 untuk kelas Problem Based Learning dan 61,35 untuk kelas Pembelajaran Langsung. Pada ukuran penyebaran data hasil posttest terdapat perbedaan varians dari kelas Problem Based Learning dan kelas Pembelajaran Langsung. Varians dan Std. Deviation masing-masing kelas Problem Based Learning sebesar 113,789 dan 10,667, sedangkan varians dan Std. Deviation kelas Pembelajaran Langsung sebesar 173,703 dan 13,180.

Pencapaian indikator kemampuan pemecahan masalah matematika siswa setelah dilakukannya posttest terlihat bahwa pencapaian setiap indikator kelas Problem Based Learning lebih besar dibanding kelas Pembelajaran Langsung. Pada indikator memahami masalah persentase ketercapaian indikator pada kelas Problem Based Learning lebih tinggi dari kelas Pembelajaran Langsung yaitu sebesar 84\%, sedangkan pada kelas Pembelajaran Langsung sebesar 83\%. Pada kelas Problem Based Learning persentase pencapaian indikator merencanakan penyelesaian masalah sebesar $65,5 \%$ dan pada kelas Pembelajaran Langsung sebesar 53,5\%. Pada indikator menyelesaikan masalah sesuai rencana persentase ketercapaian indikator pada kelas Problem Based Learning yaitu sebesar 83\%, sedangkan pada kelas Pembelajaran Langsung sebesar $60,75 \%$. Pada indikator menafsirkan hasil perbedaan persentase pencapaian indikator kemampuan pemecahan masalah matematika paling jauh perbedaannya yaitu $73,5 \%$ untuk kelas Problem Based Learning dan 44\% untuk kelas Pembelajaran Langsung.

Analisis data pada penelitian ini guna mengetahui adanya pengaruh penerapan model Problem Based Learning terhadap kemampuan pemecahan masalah matematika siswa kelas VII SMP PGRI (Disamakan) Sungguminasa, pada materi himpunan menggunakan analisis parametrik (uji-t) dalam perangkat lunak SPSS, namun sebelum melakukan uji$\mathrm{t}$ data penelitian harus diuji normalitas dan uji homogenitas terlebih dahulu sebagai uji prasyarat. Pengujian dilakukan dengan perhitungan menggunakan perangkat lunak SPSS 24, hasil uji normalitas diperoleh nilai signifikansi $0,200>0,05$ pada kelas eksperimen dan nilai signifikansi $0,148>0,05$ pada kelas kontrol sehingga dapat dikatakan bahwa kedua data tersebut berdistribusi normal .

Pada perhitungan uji homogenitas kelas eksperimen diperoleh nilai signifikansi 0,244> 0,05 sehinngga dapat dikatakan bahwa kedua data tersebut homogen. Sebelum data 


\section{Mandalika Mathematics and Education Journal \\ Volume 2 Nomor 1, Juni 2020 e-ISSN 2715-1190 | | p-ISSN 2715-8292 \\ DOI: http://dx.doi.org/10.29303/mandalika.v2i1.1775}

dianalisis menggunnakan uji-t, data kemampuan pemecahan masalah siswa dikelompokkan berdasarkan kelas masing-masing yaitu kelas eksperimen dan kelas kontrol. Hal ini dilakukan guna mempermudah dalam proses analisis data.

\section{PENUTUP}

Hasil analisis data $t$-test menunjukkan bahwa kemampuan pemecahan masalah siswa pada kelas eksperimen yang diajar dengan menggunakan model Problem Based Learning lebih baik dibandingkan dengan pemecahan masalah siswa dikelas kontrol yang diajar dengan model pembelajaran langsung. Diperoleh hasil analisis dengan menggunakan uji $\mathrm{t}$ (independent sample t-test) taraf signifikansi 5\% tampak bahwa nilai p (sig.(2-tailed)) adalah $0,000<0,05$, Ini berarti $\mathrm{H}_{0}$ ditolak dan $\mathrm{H}_{1}$ diterima yakni kemampuan pemecahan masalah matematis siswa pada kelas eksperimen lebih tinggi dari kemampuan pemecahan masalah matemati siswa yang diajar pada kelas kontrol

\section{UCAPAN TERIMA KASIH}

Terima kasih kepada seluruh staf, tenaga pengajar dan kepala sekolah SMP PGRI (disamakan) Sungguminasa.

\section{REFERENSI}

Cahyani, Hesti. Dkk. 2016. Pentingnya Peningkatan Kemampuan Pemecahan Masalah melalui PBL untuk Mempersiapkan Generasi Unggul Menghadapi MEA. Seminar Nasional Matematika X Universitas Negeri Semarang.

Fahrurrozi. 2016. Pengaruh Pembelajaran Missouri Mathematics Projet (MMP) Terhadap Kemampuan Pemecahan Masalah Matematika Siswa. Laporan Penelitian Universitas Hamzanwadi.

Maulyda, M. A., Hidayati, V. R., Rosyidah, A. N. K., \& Nurmawanti, I. (2019). Problemsolving ability of primary school teachers based on Polya's method in Mataram City. PYTHAGORAS: Jurnal Pendidikan Matematika, 14(2), 139-149.

Risdiyanto, Eko. Dkk. 2012. Pengaruh Model Pembalajaran Langsung (Direct Instruction) Melalui Media Animasi Berbasis Macromedia Flash Terhadap Minat Belajar Dan Pemahaman Konsep Fisika Siswa Di Sma Plus Negeri 7 Kota Bengkulu. Program Studi Pendidikan Fisika Jurusan Pendidikan MIPA Fakultas Keguruan dan Ilmu Pendidikan Universitas Bengkulu.

Sesa, Resta. 2017. Pengaruh Model Pembelajaran Kooperatif Tipe Two Stay Two Stray (TSTS) and Give Question Terhadap Kemampuan Pemahaman Konsep Matematika, Pemecahan Masalah dan Keterlibatan Siswa Kelas VIII SMP Negeri 8 Makassar. Skripsi Program Pasca Sarjana UNM 
Shoimin, Aris. 2014. 68 Model Pembelajaran Inovatif Dalam Kurikulum 2013. Yogyakarta: Ar-Ruzz Media.

Maulyda, M. A., Hidayati, V. R., Rosyidah, A. N. K., \& Nurmawanti, I. (2019). Problemsolving ability of primary school teachers based on Polya's method in Mataram City. PYTHAGORAS: Jurnal Pendidikan Matematika, 14(2), 139-149.

Sugiyono. (2012). Wawancara Sebagai Metode Penelitian (2nd ed.). SPSS.

Suprihatiningrum, J. 2013. Strategi Pembelajaran: Teori \& Aplikasi, (Yogjakarta: ArRuzz Media

Supriyono. Wilanda, R.A. 2014. Penerapan Model Pembelajaran Langsung Untuk Meningkatkan Hasil Belajar Pada Tema Peristiwa Disekolah Dasar. PGSD FIP Universitas Negeri Surabaya.

Surya E., \& Syahputra, E. 2017. Improving High-Level Thinking Skills by Development of Learning PBL Approach on the Learning Mathematics For Senior High School Students. International Education Studies. Vol. 10, No 8.

http://doi.org/10.5539/ies.v10n8pl 